\title{
Joint Ventures between Online Portals and News Publishers: Will they be an Alternative to Symbiosis?
}

\author{
Min Ho Ryu ${ }^{1}{ }^{(\mathbb{B}}$, Jieun Park ${ }^{2}$ and Kyu Tae Kwak ${ }^{3, * \mathbb{C}}$ \\ 1 Department of Management Information Systems, Dong-A University, Busan 49236, Korea; \\ ryumh12@dau.ac.kr \\ 2 Korea Institute of Science and Technology, Seoul 02792, Korea; jepark@kist.re.kr \\ 3 Department of Global Culture Industry, Soonchunhyang University, Asan 31538, Korea \\ * Correspondence: ktkwak@sch.ac.kr; Tel.: +82-41-530-4958
}

Received: 18 March 2020; Accepted: 15 April 2020; Published: 16 April 2020

\begin{abstract}
Around the world, legacy news publishers are suffering from the deep decline of revenues and face the challenge of survival. As the situation continues, conflicts between online portal and news producers are also intensifying. Under these circumstances, Naver, the biggest internet portal in Korea, and several Korean news publishers have begun to seek a new breakthrough-media joint ventures. The joint venture between online portals and news publishers is a unique collaboration model that has not been found in other countries. This study investigates the motivation of the media joint ventures and evaluates the performance. To do this, the study suggests the sustainability of media joint ventures. This model consists of five major categories of media joint ventures' performances, based on their strategic, financial, learning, managerial, and social influence aspects. After conducting an in-depth interview of media joint ventures and a focus group interview with nine experts from the media industry and business scholarships, the study shows that the media joint ventures could be a new alternative for both portals and news publishers. However, there were some differences in the sustainability evaluation of the operating body of the joint venture and outside experts.
\end{abstract}

Keywords: joint venture; strategic alliance; media joint venture; joint venture performance; Naver

\section{Introduction}

Print news media are no longer major news sources for many people. News consumers prefer online, mobile news that provides fast and convenient news services. Social media sites have surpassed print news and their news websites [1]. One out of five US adults said that they get news from social media rather than print news, according to a survey conducted by Pew Research in 2017. Such statistics show how fast people's news consumption patterns change. Another recent survey revealed that over half of the social media users of today have no experience of reading news from print newspapers [2]. In this digital and mobile era, it is not an outrageous idea that online platforms, including portals or social media, may replace people's news consumption.

Such news consumption trends directly affect the financial challenge of legacy news media, as is particularly serious in the Korean market [3]. Naver (Naver is a media corporation with 121 subsidiaries. In fiscal year of 2019, Naver generated 6.6 trillion Korean won (IFRS 2019.12) and is a KOSPI listed company that is worth over 27 trillion won [4]. Along with an online portal service, it also includes LINE, a mobile messenger, and V-LIVE, a global OTT service. Naver was also ranked as Korea's most frequently visited online service (38\% of UV share) in the year of 2018 [5]), Korea's number-one search-engine portal, provides news aggregation services and has been Korea's most popular and dominant news service. When Naver started to dominate the Korean news market, threatening traditional news publishers, the relationship between the two became difficult [6]. As a 
means to achieve 'symbiosis' and to ameliorate their intense relationship, Naver and Korean news publishers have attempted several measures, such as having Naver share some parts of their advertising revenue with the news publishers, or Naver paying news content fee to the news publishers. However, such measures did not turn out to be very effective. As a new potential solution, Naver and several Korean news publishers established joint ventures. Starting with its first venture 'JOB\&' in 2016, Naver had participated in thirteen such ventures by 2017.

A joint venture between an online news aggregator and legacy media publication is a unique model that has not been found in any other country. Although there are news portal services in many countries, such as Yahoo News, under existing models, the relationship between portal and newspaper companies were limited to simple content providers and buyers (or users). This is also a new area in academia; few studies have covered partnerships between an online portal/platform and news publishers. Considering that it is so new, the success or effectiveness of this model is still in question. We intend to investigate the joint ventures formed between the Korean portal Naver and Korean news publishers and their future prospect as a strategy to achieve symbiosis and growth in the Korean news market.

Only a few works in literature demonstrate strategic motivations of news joint ventures. One study compared conventional news with online news from the perspective of journalism [3,7], while another study attempted to design a revenue-sharing model for a portal and news publishers [6,8]. Nonetheless, much more studies are needed for how and why a joint venture between a portal and news publishers was established, the main traits of this particular strategic alliance, and for the upsides and downsides of this alliance. A performance evaluation method for this kind of media joint venture, in particular, has not yet been performed.

This study attempts to provide answers to the following questions: First, will those joint ventures serve as a new revenue-generating business model for Korean news publishers? Second, will the joint ventures help Korean news publishers expand their business to, for instance, service journalism like soft news? And third, would the creation of a joint venture ultimately help Korean news publishers be more competitive in terms of content creation or profit-making?

This study summarizes the status of the thirteen joint ventures formed between Naver and Korean news publishers. Among the thirteen joint ventures, this study conducted in-depth focus-group interviews (FGI) with four of them and carried out an evaluation on their performance and sustainability. Furthermore, we held a separate, second round of FGI to listen to experts' objective assessments of joint ventures' performance. The following section elaborates on the history, background, and status quo of the partnerships between an online portal and the news publishers of Korea. Then, we provide a thorough literature review on joint ventures and their performance evaluation studies. Based on the literature review and analysis, we suggest a model for evaluating the performance of joint ventures. In the following section, we discuss the research method and detailed information about the interviewees. Finally, we present the results, findings, and implications for future study.

\section{Drivers of Joint Ventures between an Online Portal and News Publishers}

Around the world, traditional newspapers face the challenge of survival. There are some differences between countries, but in most countries, newspapers are becoming increasingly dependent on platform operators such as Google and Facebook. As such, media companies losing in the race for leadership with a giant platform operator it is not unique to Korea. However, the position of the portal in the history of Korean Internet media is unique [5].

South Korea's news publishers initially offered news to online portals at a certain price and allowed an in-link news service that allowed articles to remain in a portal's DB. Because of this in-link approach, Korean news publishers are so highly dependent on portals that they can hardly be seen around the world. About 77 percent of South Korean readers are reported to have access to news via online portals, which confirms how much South Korean news users rely on portal media, compared to the average of $30 \%$ in 36 other countries. In addition, the ratio of direct visits to news publishers' homepages is 4 
percent, which is the lowest in the world [9]. In the following sub-sections, we will investigate factors contributed to the emergence of joint ventures between Korean portals and news publishers.

\subsection{Perspective of Online Portal and News Publishers' Relationship}

This sub-section investigates how relationships between online portals and news publishers have changed, and in what context joint ventures started to be established. Understanding the history of the Korean online news market landscape helps us understand the context of the creation of joint ventures.

Before 2000, the Korean newspaper industry was dominated by the top three newspapers (Chosun Ilbo, Joong-ang Ilbo and Dong-A Ilbo), which account for more than 70 percent of the total circulation [9].

In 2000, internet portals such as Naver and Daum launched their news service, simply placing news title links on the front page [10]. The year 2002 had many issues and national events for Korean society. In such a big surge of news, portals like Naver conveniently provided an organized, all-in-one news-platform service to Korean news viewers and quickly began to win the market over the news companies. In 2003, portals surpassed the news publishers' online services in user numbers [7] (Figure 1).

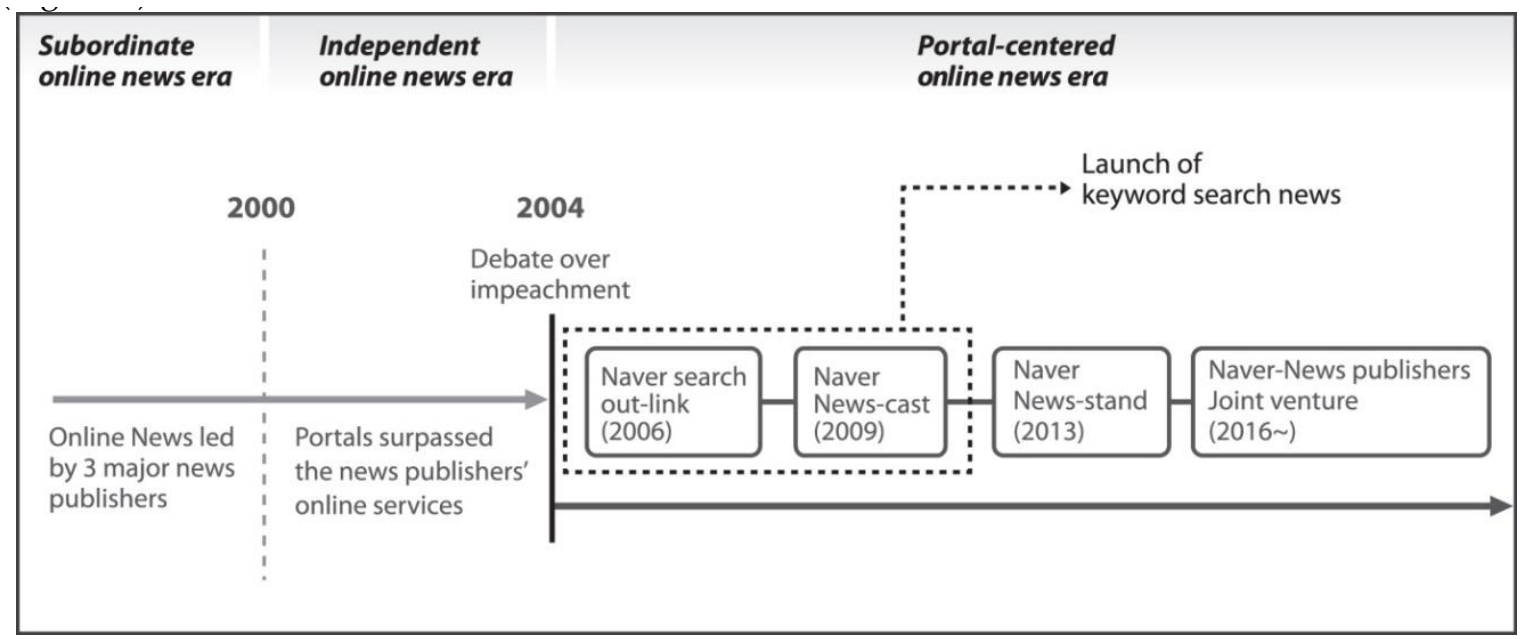

Figure 1. History of Korean online news market landscape.

Since then, uncomfortable relations between Internet portals and traditional newspapers have continued. News publishers argue that portals are making huge profits by taking news without paying for it, and thus internet portals should pay more for their news content. To resolve this unpleasant situation, Naver launched a news 'out-link' service in 2006, through which users are directly sent off to the online website of a news article that the users had searched for on Naver [11]. As the traffic generated by the offline delivery of news on portal mains flows to individual media outlets, media companies have received huge traffic through portals, providing an opportunity to expand their advertising revenue [12]. It was the alleged intention of Naver to 'co-exist' with the news publishers in the market. However, this out-links service brought about an unexpected outcome. In order to increase the amount of traffic coming from portals, media outlets competitively posted articles with sensational and provocative titles, and some types of tabloid news, particularly from the sports and entertainment area, overwhelmed the online news [13].

Fierce debates over the role of portals in the news industry and acknowledgment of a problem with abusing news eventually led Naver to replace its Newscast service with a new type of service named Newsstand in 2013 [9]. Newsstand, unlike Newscast, displays the brand logos of each news publisher instead of a news title itself. On the front page of Naver, news users can choose a news publisher among diverse options, and then they are directed to the online website of the chosen news publisher. Within a week of the newsstand transition, the number of visitors to the media's website and page views decreased by $45.0 \%$ and $39.8 \%$, respectively [11]. 
News publishers were at a serious impasse where they generally felt that such high dependency on portals cannot be a lasting business model. Portals like Naver also contemplated getting rid of old models and finding a different, win-win strategy. It was around 2016 when Naver initiated the establishment of joint ventures. In summary, the existing model of partnership between portals and news publishers had faced serious challenges, such as news abusing, which led to harsh criticisms from the public. As a result, the quality of online news services has continued to decline, and portals and news publishers have failed to find the optimal way to coexist. Figure 1 summarizes the history of the Korean online news market.

Besides historical context, the 'mobile' waves have driven both the portals and the news publishers to do something different, thus stimulate to create the joint venture. As mobile devices spread, apps become new standards and users started to require a more customized, personalized content and services. In this situation, Naver may not satisfy users with the traditional uniform way of providing information [14]. In order to overcome this problem, Naver will look for a target to supply more quality professional content from outside. It was found that news publishers are the best partners to provide quality content continuously. Even for news publishers, joint ventures may have been perceived as new alternatives that go beyond the existing business models. Thus, it can be understood that this combination of the two organizations resulted in the creation of joint ventures.

\subsection{Naver-Korean News Publisher Joint Venture Status Quo}

Naver has formed joint ventures with thirteen different Korean news publishing companies (as of September 2018). The participating news companies are in charge of content creation and curation. Naver, on the other hand, provides yearly funds to them: one billion Korean Won (8.7 million in US dollars) is provided to every participating news publisher. Table 1 summarizes the current thirteen joint ventures.

Table 1. Summary of the current thirteen media joint ventures.

\begin{tabular}{|c|c|c|}
\hline Joint Venture (Company Name) & $\begin{array}{l}\text { Parent Company } \\
\text { (News Publisher) }\end{array}$ & $\begin{array}{l}\text { Related Expertise of the News Publishers } \\
\text { (Parent Company) }\end{array}$ \\
\hline JOB\& (JobsN) & Chosun Ilbo & $\begin{array}{c}\text { Operating a job information website } \\
<\text { Misaeng } \mathrm{A} \text { to } \mathrm{Z}>\end{array}$ \\
\hline Travel+(Yeople) & Maeil Business Newspaper & $\begin{array}{c}10 \text { years of experience as a travel } \\
\text { map publisher }\end{array}$ \\
\hline Movie (Cineplay) & Hankyoreh Shinmun & $\begin{array}{l}\text { High reputation for its expertise in cinema } \\
\text { based on its movie magazine }<\text { Cine } 21>\end{array}$ \\
\hline China (ChinaLab) & JoongAng Ilbo & $\begin{array}{l}\text { First news company to found a research } \\
\text { Centre specializing in China (Date: 2017.7) }\end{array}$ \\
\hline SchoolJam (EBS) & EBS & $\begin{array}{l}\text { Specialty in education broadcasting and } \\
\text { abundant video content }\end{array}$ \\
\hline Business (Interbiz) & The Dong-A Ilbo & $\begin{array}{l}\text { Providing high-class business content via } \\
\quad<\text { DBR(Dong-A Business Review) }>\end{array}$ \\
\hline Design (Designpress) & Design House & Expertise in design is the top priority \\
\hline Farm (Agroplus) & Korean Economic Daily & $\begin{array}{l}\text { Specialty in agro-related topics like } \\
\text { back-to-farm trend }\end{array}$ \\
\hline Concert/Exhibition (Artition) & Kyunghyang Shinmun & $\begin{array}{l}\text { Having advantage in culture or art area } \\
\text { thanks to its magazines or sections }\end{array}$ \\
\hline Legal (Law\&Media) & Money Today & $\begin{array}{l}\text { Operating a professional legal media } \\
\text { channel }<\text { the } \mathrm{L}>\end{array}$ \\
\hline Pets/Animals (Animal \& Human) & Hankook Ilbo & $\begin{array}{l}\text { Operating an animal-rights website } \\
\text { <Animal and Human }>\end{array}$ \\
\hline Marriage (Sun-lab) & Munhwa Ilbo & $\begin{array}{c}\text { Published a category } \\
<\text { Relationship \& Marriage }>\end{array}$ \\
\hline Tech(Tech-plus) & Electronic Times & The oldest IT news publisher in South Korea \\
\hline
\end{tabular}


Business models for joint ventures are largely of two types. First, the biggest source of finance is, as mentioned above, the funding from Naver. One billion Korean Won from Naver is a big-enough budget to cover most of the expenses, including labor and operating cost. From the participating news publishers' view, this is a tempting business opportunity, not only to try something risky and interesting, but also to reduce operating costs $[15,16]$. Another finance source is the advertisements in those newly created categories. The advertisements are either (1) ad banners, (2) swipe-type ads, or (3) branded content ads. One requirement that needs to be met to place ads is 2 million daily visits. Fortunately, most of the partners, including earlier members of the joint ventures, have enough visitors, successfully meeting this requirement.

A Naver-newspaper joint venture was first initiated by the Chosun Ilbo's offer to Naver about the company serving as an $\mathrm{MCP}$, or main content provider, which adds a new service of job search and startup to the current Naver platform. After a series of talks, the Chosun Ilbo and Naver agreed to create a joint venture named 'JOBS\&'. The 'JOBS\&' service took off in February 2016. After this news, other newspaper companies seemed to borrow this strategy: Maeil Business Newspaper created 'Travel+', The Hankyoreh formed 'Movie', and JoongAng Ilbo created 'China' Pan, meaning a new content category or section. In 2017, EBS, the Dong-A Ilbo, and the Korean Economic Daily subsequently added new categories. Electronic Times also jumped into this wave and took on the operation of a 'Tech' category. Some critics viewed such joint ventures as Naver's efforts to sooth the tension in its relationship with journalists. This view is supported by the fact that eleven out of the thirteen joint ventures were based on the partnership with major news publishers of Korea.

\section{Performance Evaluation of Media Joint Ventures}

In the early literature, the performance of a joint venture was evaluated based on an objective index, such as its financial performance or survival duration [17-19]. That is, most studies focused on the economic motivation of the alliance. However, the motivations behind the formation of a joint venture are rather multifarious and thus its performance should not be evaluated only by its financial performance $[20,21]$. In fact, several theories and academic fields (e.g., transaction cost economics, strategic behavior theory, and organizational learning theory) showed more diverse discussions about the motivation of an alliance like a joint venture $[19,22,23]$. A company steps into a strategic alliance with another company because, for instance, it desires to cut some of the transaction cost [24-26], to take the initiative in the market and achieve economies of scale [27,28], or to access particular sets of knowledge or core competencies to strengthen the company's strategic flexibility [29].

Studies of the late 1990s started to explore diverse aspects in performance evaluation of an alliance. Along with financial performance, scholars began to investigate the fulfillment and realization of the strategic intents [23,30], the satisfaction level of the alliance parties [31,32], or the achievement of sharing (physical, financial, technological, managerial knowledge, etc.) between the alliance parties [33-35]. Joint ventures, however, are faced with various inherent challenges that come from its partnership and organizing process [32]. For instance, the moral hazard of the partnering company may lead to the leak of key information, adverse selection, or even a hold-up effect [36,37]. In some cases, excessive learning competition between the employees or weak authorities and hierarchical structure are experienced as problems $[26,37,38]$.

Likewise, there have been various views on how to evaluate joint ventures' performances that are academically controversial [38,39]. In fact, the expected performance level for joint ventures may depend on many factors, such as the motivation behind its creation or its field. Additionally, which scope or time period of a joint venture should be covered in a performance evaluation, whether the performance should target the parent company or partnering company, or which criteria should be used for joint ventures' performance are still answered from many different perspectives [40,41]. Another point comes from the difficulty in accessing necessary data, such as contract content and the performance derived from the partnership. 
Nevertheless, there is much strategic management literature about how to measure and evaluate the performance of a strategic partnership and joint venture, which is one type of strategic partnership. Early studies generally focused on the financial aspect of joint ventures for evaluating performance $[17,18]$. Then, later studies began to take a more holistic approach by embracing non-financial performance along with financial performance [41]. For instance, based on a three-level model of performance (financial, operational/business, organization) suggested by Venkatraman and Ramanujam [42], scholars started to specify dimensions of a joint venture's performance that include strategy, governance, economics, organization, and knowledge [30,43-45]. It is crucial to note that an evaluation of a joint venture's performance can depend on the venture's type or the evaluator's perspective; so the non-financial side should be included and investigated in joint venture performance evaluation studies [46,47]. This is, in fact, reflected in some of the latest research, where the performance analysis is divided into three different levels (dyad, portfolio, firm level), or where the performance of a joint venture was evaluated both by numbers (financial performance) and subjective evaluation from the partners $[20,48]$. Further, some studies examine the venture's portfolio, along with the performance of the parent and partner companies [23,49].

The methodology of evaluating the performance of joint ventures evolved to combine the non-financial side of performance with the financial one, to include the long-term outcome along with the short-term one, to consider not only the result but also the process, and to examine both measurable and non-measurable performances [50]. That is, the performance of a joint venture is evaluated by both financial and non-financial outcomes, based on the venture's strategic motivation. Based on such a literature review, we develop a performance evaluation framework for joint ventures that includes joint ventures' strategic motivations, the systemicity of the performance evaluation model, and the traits of joint venture projects.

This study, also, attempts to integrate the 'economic-strategy-governance-organization' performance evaluation model category from Bamford and colleagues' study [43], along with the 'economic-strategic-behavioral-learning (knowledge)' performance evaluation classification from Büchel and Thuy [44]. In order to make the concepts clear, we adjusted 'behavioral performance' from Büchel and Thuy's model to 'managerial performance' and added 'governance' and 'organization' as its performance indicator. Adjusting to the specific context of joint ventures between an online portal and newspaper companies, this study newly included a 'social influence' category for joint venture performance evaluation.

For instance, 'financial performance' evaluates the financing, equity, sales revenues, profit-sharing, and cost control. As for 'strategic performance', this study defines the strategic intention of such joint ventures being established and its competitiveness, marketability, etc. For 'managerial performance', this study evaluates the governance, commitment, and operational stability of the joint ventures. 'Learning performance' examines the acquired capability, knowledge sharing, and problem-solving skills. This, in particular, is strongly associated with the incubation and sharing of technological knowledge, which can contribute to the improved problem-solving skills in business. Lastly, 'social influence' examines the content diversity, social evaluation, and sustainability of the joint ventures. The final five categories and evaluation items for each of the categories are shown in Figure 2. 


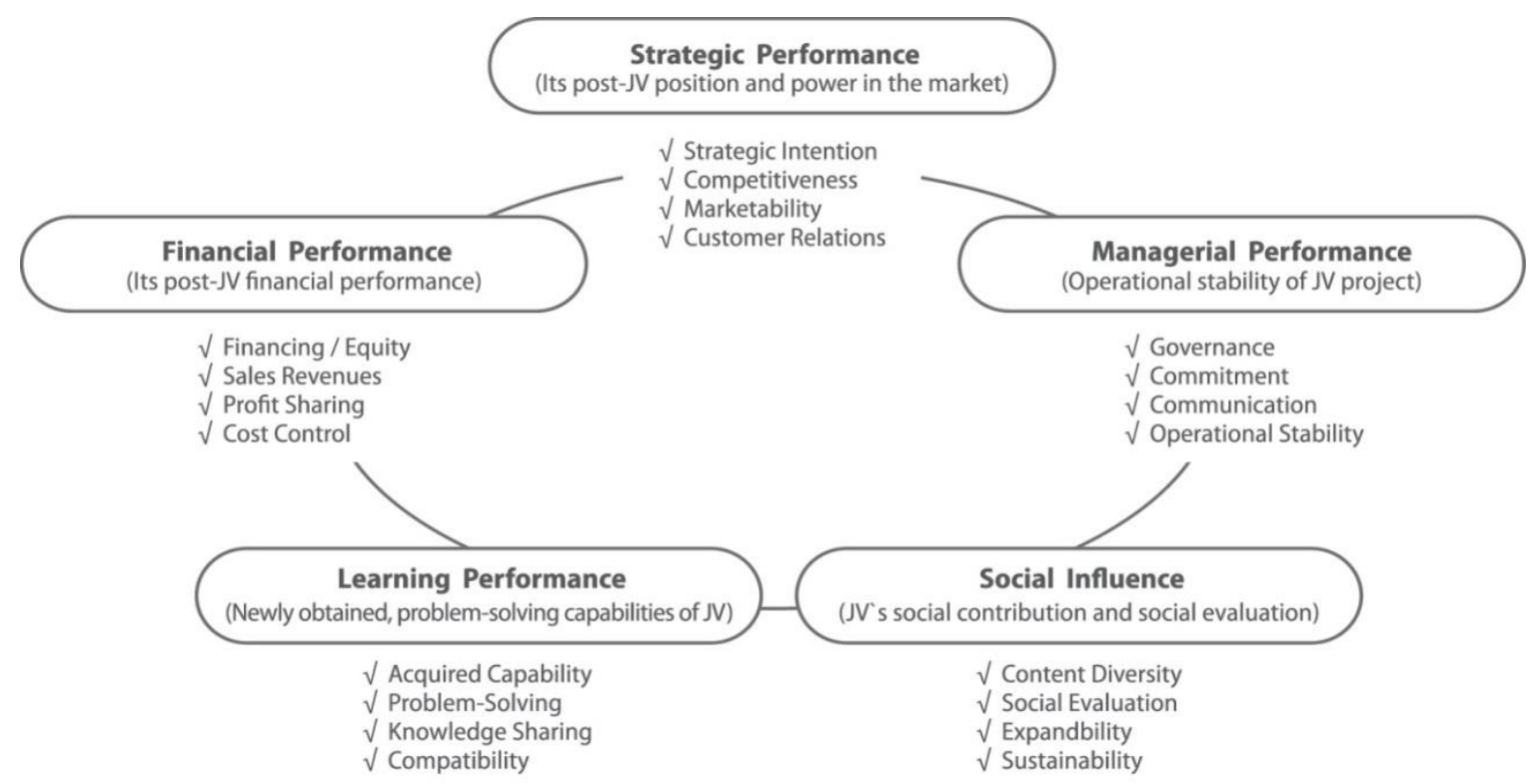

Figure 2. Performance evaluation model for media joint ventures (five categories and its indicators).

\section{Research Method}

This study relies on the data that are collected by interviews. Interviewing is a typical research method in qualitative research [51]. Primary data were gathered by conducting semi-structured interviews. For this study, an interview guide containing several open-ended questions was used. Five to seven key questions were included for each of the five performance measurement areas described in Figure 2. When using semi-structured interviews, the wording and order of questions are often modified based on the response of the interviewees.

This study takes a two-step approach in terms of data collection. First, we conducted an in-depth interview with four joint ventures that have different characteristics out of the thirteen joint ventures. The selected four are (1) JOB\&, the first joint venture by a legacy media, (2) FARM, a pioneer in agro-content, (3) Designhouse, which holds a specialty as a magazine, and (4) SchoolJam, providing mostly video content instead of text. Focus-group interviews revolved around a pre-prepared list of questions on the following five categories: financial performance, strategic performance, managerial performance, learning performance, and social influence. The interviews were conducted between July and August in 2018. The interview questionnaire was sent to interviewees before the actual face-to-face interview. The interviewees were affiliated with entities belonging to one of the joint ventures. All individuals interviewed are representative of the joint ventures. Table A1 shows detailed facts of the investigated joint ventures.

Along with interviewing joint venture managers, this study has also conducted a focus group interview and in-depth interview with nine experts. The experts interviewed for this study are divided into two groups: media industry and academia. The six media experts are diverse in background: a journalist with experience in news joint ventures, another journalist who is currently seeking a chance to join a joint venture, a scholar with new-media interest, and a reporter who has participated in a news startup. They were first interviewed in writing and then gathered on October 7, 2018, for the in-depth interview as a group. On the other hand, three other experts from academic field were also interviewed, so that important implications for the evaluation of joint venture business performance (e.g., financial, managerial, learning performances) could be provided. The three experts from management, strategy or marketing areas were also interviewed in writing first and then participated in a face-to-face interview on October 17, 2018. Unlike the media industry expert groups, these three were interviewed individually on the same day. A summary of the interview results is shown in Table 2. 
Table 2. Summary of interviewees.

\begin{tabular}{cccc}
\hline Category & Interviewee & Occupation & Specific Field \\
\hline & $\mathrm{A}, \mathrm{B}$ & Reporter (PC) & News media \\
Media & $\mathrm{C}$ & Researcher (JV) & Media management and economics \\
Industry & $\mathrm{D}$ & Department Head (JV) & Online content \\
Experts & $\mathrm{E}$ & Chief of Division (JV) & Online news business \\
& $\mathrm{F}$ & President (JV) & News media startup \\
\hline \multirow{3}{*}{ Academic Experts } & $\mathrm{G}$ & Professor & Organization/Management \\
& $\mathrm{H}$ & Professor & Strategy/Alliance \\
& $\mathrm{I}$ & Professor & Marketing \\
\hline
\end{tabular}

JV (joint venture), PC (parent company).

\section{Results}

\subsection{Motivation behind the Joint Venture Creation between Naver and Newspaper Companies}

Naver considered three aspects in reviewing potential joint venture ideas. The first aspect is the existence of a robust business ecosystem. Second, there must be an abundant supply of content, meaning many content providers or creators. Third, the item should be socially good. Based on these three criteria, Naver selected their joint venture partners, with which it can vertically expand its business in order to ultimately defeat the existing professional applications. It is not an exaggeration to say that the joint venture strategy was the beginning of Naver's new mobile content strategies.

Meanwhile, some critics view such joint ventures as Naver's efforts to sooth the tension in its relationship with journalists. Allegedly, it was Naver's strategic move to handle the criticism and worries from the news publishers. This view is supported by the fact that eleven out of the thirteen joint ventures are based on the partnership with major news publishers of Korea.

Likewise, forming a joint venture with Naver was a good business chance to try something innovative and low risk. Newspaper companies were, like any other company, under the pressure of designing a new business model for today's fast-changing technology and audiences. One billion Won worth of annual funds from Naver has erased a large portion of financial burden from news publishers. That is, Naver contributed in lifting this burden for newspaper companies coming from new business challenges like mobile services. Some of the participating news publishers expected to add a 'digital' value to its services, at which most of the newspaper companies are quite weak, by establishing a joint venture with Naver. Another of the newspaper companies' motivation was to use Naver's portal platform for something challenging and innovative. It certainly is too soon to have a complete performance evaluation for the joint ventures. However, devising a model to evaluate their performance is necessary for the joint ventures' sustainability.

Using the news joint venture evaluation model, results from the interviews are provided on five levels. The results are provided in two parts: one from the managers of the joint ventures and the other one from the nine experts (see Table 3 for the summary).

\subsection{Joint Venture Performance Evaluation from the Participants}

- [Strategic Performance] The joint ventures were a part of Naver's mobile service strategies. Online platforms hold strength in their user base but weakness in content production. News publishers, in contrast, can create content, but often have difficulty in effectively distributing it. Thus, the managers regarded forming a joint venture between the two is a win-win strategy, complementing each other's weak points.

- $\quad$ [Financial Performance] Naver provides one billion Korean Won every year to the joint ventures. The joint ventures can also draw additional financial resources through advertisements or selling their content to other third platforms. However, the joint ventures must show an average of two million daily visits to their site in order to place ads. What was found from the interviews is how 
greatly most of the joint ventures depend on Naver funds. Certainly, there exist some promising cases. Several early members like JOB\& have made profits from their content sales to the third platforms. Additionally, some other ventures showed potential for better financial performances in the long run.

- [Managerial Performance] The news publishers (parent company) are willing to keep an eye on the ventures, but are reluctant to concentrate on and fully support them. For them, this is more of an experiment. The interviewed managers mentioned that major improvement is needed in three realms: (1) increase the number of content production workers, (2) provide stronger support in management for the ventures, and (3) devise a more effective and proper compensation system for dispatched workers. Further, for the joint ventures to succeed, both the parent companies and Naver need to pay greater attention to this business and extra efforts in communicating with the ventures.

- $\quad$ [Learning Performance] The managers pointed out that their joint venture with Naver provided them with an opportunity to (1) better understand the online market and users, and (2) learn about Naver's organizational culture that truly promotes innovation. These know-hows and knowledge will later become a seed of innovation in the parent companies.

- [Social Influence] Thanks to the joint venture, participating news publishers not only became more competitive, but also gained better reputation and more partnership offers as well. In a sense, it helped the entire business ecosystem grow. Despite the fact that there are currently only thirteen participating companies, the managers expected, or even hoped, that more players would join as the ecosystem expands. A whole new area of content, which none of the current thirteen companies cover, can be added, or a second or third player in the existing area may emerge. Moreover, the act of forming a joint venture between Naver and news publishers may also imply the first step of putting the exhausting strife behind and moving forward together.

\subsection{Joint Venture Performance Evaluation from Outside Experts}

- [Strategic Performance] Experts explained that the key strategic motive behind this portal-news companies' partnership is two-fold: (1) procuring a diversity of online content for users with diversified needs and wants, and (2) gaining tighter control over the content while showing a response toward news publishers' complaints about the fees they pay to Naver. One billion Won worth of funds and getting access to run services on the Naver platform are definitely upsides, but structurally, the parent companies' intervention and control over the ventures discourage its potential for expanding business and experiment, according to the interviewed experts.

- [Financial Performance] Financially, the joint ventures primarily relied on the seed money from Naver and lacked capacity in profitability and investment scalability. Improvement in content quality and renewal of a content-exposure strategy are crucial to future revenue increase. The experts suggested the following ideas as solutions: strengthening video content that are based on users' demands and are suitable for cross platform ads, sharing user information across platforms, diversifying business models, improving the current incentive system, and developing a new pipe of finance resource.

- [Managerial Performance] Low autonomy in management and insufficient support from the parent company were identified as problems. Management in human resource and business administration were the two most critical areas. The interviewed experts recommended ensuring the appointment of a competent $\mathrm{CEO}$ with a professional background, building a system that can make employment more stable and promote performance, and considering a multi-stakeholder alliance model [52]. Further, the development and sharing of successful cases and the sharing of key knowledge for making profits are also pressing matters.

- [Learning Performance] Naver can obtain content creation, sourcing, and editing skills of news publishers, while news publishers can more systematically learn about online users' demands and responses to online content. To improve learning performance, it is necessary to have more 
professional, competent partners. Another crucial point is that all parent companies should pay greater attention to outputs from the joint ventures and seek ways to work together as a win-win strategy.

- [Social Influence] There are two contrasting views on the joint ventures from two groups: the ones participating in the joint venture, and the ones not participating. Academic scholars pointed out that content distribution and quality control are the positive sides of the ventures, but what also needs to be considered is a potential public bias created by the dominance of content from Naver and a particular news publisher. The experts also mentioned that how a joint venture is formed, overall corporate governance and business transparency need to be ameliorated.

Table 3. Key findings from company interviews and expert interviews.

\begin{tabular}{|c|c|c|}
\hline Category & Company Interviews & Expert Interviews \\
\hline $\begin{array}{l}\text { Financial } \\
\text { Performance }\end{array}$ & $\begin{array}{l}\text { Several early members like JOB\& have } \\
\text { made profits from content sales to the third } \\
\text { platforms. Additionally, some other } \\
\text { ventures showed the potential for better } \\
\text { financial performances in the long run. }\end{array}$ & $\begin{array}{l}\text { The joint ventures primarily relied } \\
\text { on the seed money from Naver } \\
\text { and lacked capacity in profitability } \\
\text { and investment scalability. }\end{array}$ \\
\hline $\begin{array}{c}\text { Strategic } \\
\text { Performance }\end{array}$ & $\begin{array}{l}\text { The joint venture between the two is a } \\
\text { win-win strategy, complementing each } \\
\text { other's weak points. }\end{array}$ & $\begin{array}{l}\text { Transparency of the process for } \\
\text { selecting a partner for joint } \\
\text { ventures is important. }\end{array}$ \\
\hline $\begin{array}{l}\text { Managerial } \\
\text { Performance }\end{array}$ & $\begin{array}{l}\text { More support of human and financial } \\
\text { resources is required. }\end{array}$ & $\begin{array}{c}\text { Low autonomy in management } \\
\text { and insufficient support from the } \\
\text { parent company were identified as } \\
\text { problems. }\end{array}$ \\
\hline $\begin{array}{l}\text { Learning } \\
\text { Performance }\end{array}$ & \multicolumn{2}{|c|}{$\begin{array}{l}\text { The joint ventures provide both parties (Naver and news publishers) with an } \\
\text { opportunity to learn from each other. }\end{array}$} \\
\hline $\begin{array}{l}\text { Social } \\
\text { Influence }\end{array}$ & $\begin{array}{l}\text { The joint ventures helped the entire } \\
\text { business ecosystem grow. }\end{array}$ & $\begin{array}{c}\text { Overall corporate governance and } \\
\text { business transparency need to be } \\
\text { ameliorated. }\end{array}$ \\
\hline
\end{tabular}

\section{Discussion and Implications}

In conclusion, this study investigated the motivation and background of a new kind of media joint venture between legacy news media and an online portal, evaluated its performance, and suggested the sustainability of such media joint ventures. Using the literature review and in-depth interview, this research identified and overviewed the thirteen joint ventures formed between Naver and Korean news publishers. This study, moreover, selected and specifically investigated four joint venture cases among the thirteen, in an attempt to evaluate their performances in the market. Adopting and adjusting Büchel and Thuy [44]'s model to the specific context of joint ventures between portal and newspaper companies, this study suggested a performance evaluation model with five evaluation items. The five items include financial performance, strategic performance managerial performance, learning performance, and social influence.

It was examined that one of the key drivers of joint ventures in Korea is the portals trying to respond to the 'mobile app' trend. Different from the global market, Korean portals were also confronted with a lack of 'Korean' data. It is unlikely for global portal players to face a content-supply issue, but for Korea it was indeed the case, because there was too little Korean-based content. Seeing such a dire lack of Korean content and data, the portal players took the lead in developing and promoting a Korean-based content industry. It is our analysis that the joint ventures between Naver and the news publishers, in a way, strengthened the ecosystem and showed the possibility of a new, sustainable business model. Indeed, there are some criticisms over how limited the participation of news publishers is. However, a solution probably lies in a long-term, step-by-step plan, not in a 'doing-nothing' approach. 
Nonetheless, many of the interviewees mentioned that the parent companies' professional values or skills are not yet fully shared [46] and fueled into the joint ventures. The experts pointed out that the ventures may need to take a market differentiation strategy, in a vertical sense, by regularly producing original content $[39,48]$. Potentials of the joint ventures to expand service journalism, where they can develop the soft news area of the legacy media, were implied as an example of successful performance. Additionally, it was the unusual relationship between the portal and news publishers in Korea that drove the birth of these joint ventures. From the perspective of a performance-evaluation model borrowed from the business-management field, the current performance level of the ventures is merely noticeable or meaningful. The experts highlighted that a significant change in the attitude and perception from both Naver and the parent companies is mandatory $[40,46]$, if they hope for the sustainable growth and success of their joint ventures.

Another finding was how differently the two groups of interviewees, the managers and experts, analyzed the performance of the joint ventures. Naver and the participating news publishers said that the major motivation for this kind of joint venture was content innovation and mobile strategy. However, the experts regarded the existing tension over the fee that news publishers pay to Naver as the main motivation. Potential supports, from the experts' view, can be a long-held tension between the portal and news publishers [34,41], partners consisting mainly of major big news publishers, etc. All these factors should be carefully considered for developing a future joint venture model.

However, there are several concerns and future assignments to be handled, in order to make the joint ventures sufficiently sustainable. First, some of the interviewees underlined a point to be reviewed: is the joint venture really the best and the only solution when other options seem to be available (e.g., strategic alliance, a content partnership)? According to the experts, the best form of collaboration must consist of technological knowledge from the portal and content production skills from the news publishers [21,23,46]. Additionally, how much attention and support Naver and the parent companies provide to the ventures may determine the joint ventures' future. Aside from the support itself, the experts also emphasized the transparency along the support-execution process $[17,24]$.

Another concern lies in the weak financial capacity of the joint ventures. Economic and financial aspects were not the most crucial factors in the beginning phase of the joint ventures $[44,45]$. This led the ventures to have weak financial sustainability from the business aspect. Joint ventures, perhaps naïvely, do not own an intense motivation for finance. What they need to focus on is developing and amplifying their strong points. The experts commented that the joint ventures must show a certain level of financial stability and independence in order to extinguish many of the current criticisms.

The last, but most crucial, future assignment for the joint ventures is whether their content ecosystem can expand. Although there are many stakeholders in the market, the content industry has hardly been perceived as being profitable, because it is highly segmented and thus the players are scattered. The joint ventures between Naver and news publishers serve not only as a core to bring content players onto a single ground, but also as a catalyst to the ecosystem. A bigger and healthier ecosystem will lead to more diversified business models [36,43], which will ultimately lead to the development of innovative, completely new content businesses. However, for now, the business is limited to only thirteen areas and the participants are mostly from major newspaper companies. Such facts make us doubt that great ecosystem growth is possible. The players need to encourage new players with different backgrounds and perhaps even from different industries to join the ecosystem by making investments in the content business. Under a more open governance, those investments from diverse players may channel into some of the joint ventures, which in the end would help the entire ecosystem be healthy and sustainable $[53,54]$.

This study is not without limitations, despite its contribution. First, the two-year history of joint ventures between an online portal and news publisher is simply too short, thus providing too little data to analyze the performance of joint ventures. There needs to be a continuous check and monitoring on the performance of joint ventures. Second, although this study suggested a media joint venture 
performance evaluation model, it has a limitation in that it mostly depended on qualitative data and lacked quantitative data. Further studies should apply a more quantitative and statistical method to evaluate such media joint ventures. Third, an addition of the 'technological performance' category may be necessary, particularly in a high-tech media business field. Moreover, despite our best efforts, we could investigate only four cases out of all thirteen joint ventures. Obtaining more case samples may be necessary to improve the representativeness of research findings. Lastly, this study only included interviews from the managers and experts, excluding actual service users or news content creators. A wider range of stakeholders should be considered and included in a further media joint venture study.

Author Contributions: All authors contributed equally to the research presented in this paper and to the preparation of the final manuscript. Writing — original draft, M.H.R., J.P., and K.T.K.

Funding: This work was supported by the Dong-A University Research fund.

Conflicts of Interest: The authors declare no conflict of interest. 


\section{Appendix A}

Table A1. Facts and figures of the interviewed media joint ventures.

\begin{tabular}{|c|c|c|c|c|c|c|c|}
\hline Joint Venture & Subscribers & $\begin{array}{l}\text { Days to Break } 200 \\
\text { Thousand Viewers }\end{array}$ & $\begin{array}{l}\text { Content Uploaded } \\
\text { (per Day) }\end{array}$ & $\begin{array}{l}\text { Content: (Original, } \\
\text { Outsourced) }\end{array}$ & $\begin{array}{l}\text { Type of Curated } \\
\text { Content }\end{array}$ & $\begin{array}{c}\text { Sales (W) } \\
\text { (Operation Costs } \\
\text { and Others) }\end{array}$ & Service Expansion Plan \\
\hline Job\& & $\begin{array}{l}3.75 \text { million (as } \\
\text { of July 2017) }\end{array}$ & 15 days & 60 pieces & 10 original & $\begin{array}{l}\text { Content from other } \\
\text { news publishers, } \\
\text { blog posts }\end{array}$ & $\begin{array}{l}3 \text { billion as of } 2017 \\
\text { (including } 1 \text { billionof } \\
\text { operation cost) }\end{array}$ & $\begin{array}{l}\text { Content business (e.g., } \\
\text { education, job-seeking, etc.) }\end{array}$ \\
\hline Farm & $\begin{array}{l}2.3 \text { million (as of } \\
\text { April 2018) }\end{array}$ & 8-9 months & 30 pieces & $\begin{array}{l}7 \text { original, } 20 \\
\text { outsourced }\end{array}$ & $\begin{array}{l}\text { Blog posts, online } \\
\text { content published } \\
\text { by the government }\end{array}$ & Refused to disclose & $\begin{array}{l}\text { FarmTech Forum, } \\
\text { Smart-farm projects, } \\
\text { shopping mall, etc. }\end{array}$ \\
\hline Designhouse & N/A & 1 year & 80 pieces & 7 7.5 original & $\begin{array}{l}\text { Content from other } \\
\text { news publishers, } \\
\text { professional blog } \\
\text { posts from agencies }\end{array}$ & $\begin{array}{l}1 \text { billion of operation } \\
\text { cost ( } 50 \text { million } \\
\text { asrevenue from ads) }\end{array}$ & $\begin{array}{l}\text { Planning exhibits and } \\
\text { spaces, designing talk } \\
\text { program, etc. }\end{array}$ \\
\hline SchoolJam & $\begin{array}{l}1.7 \text { million (as of } \\
\text { June 2018) }\end{array}$ & 8 months & 50 pieces & $\begin{array}{c}50 \text { original ( } 30 \% \text { of } \\
165 \text { monthly } \\
\text { uploads) }\end{array}$ & $\begin{array}{l}\text { Content from other } \\
\text { news publishers } \\
\text { (high share } \\
\text { oforiginal content) }\end{array}$ & $\begin{array}{c}1 \text { billion of operation } \\
\text { cost }\end{array}$ & $\begin{array}{c}\text { Producing more original } \\
\text { content }\end{array}$ \\
\hline
\end{tabular}




\section{References}

1. Rutenberg, J. News Outlets to Seek Bargaining Rights Against Google and Facebook. The New York Times, July 2017. Available online: https://www.nytimes.com/2017/07/09/business/media/google-facebook-newsmedia-alliance.html (accessed on 10 March 2020).

2. Korea Press Foundation. 2017 Social Media User Survey; Korea Press Foundation: Seoul, Korea, 2017; pp. 44-56. ISBN 978-89-5711-485-8. (Written in Korean)

3. Hong, A.; Nam, C.; Kim, S. A customer-based indirect approach to determine the value of news provided to Internet portals in Korea. Telemat. Inform. 2018, 35, 1718-1732. [CrossRef]

4. Financial Supervisory Service of ROK. DART (Data Analysis, Retrieval and Transfer System). April 2020. Available online: http://dart.fss.or.kr (accessed on 10 March 2020).

5. Korea Internet Security Agency. 2018 Korea Internet White Paper. February 2019. Available online: https://www.msit.go.kr/web/msipContents/contentsView.do?cateId=_tsta6111\&artId=2629699 (accessed on 10 March 2020).

6. Kwak, K.T.; Hong, S.C.; Lee, S.W. An Analysis of a Repetitive News Display Phenomenon in the Digital News Ecosystem. Sustainability 2018, 10, 4736. [CrossRef]

7. Song, H.Y.; Yang, J.H. Online News Portal Service and Changes in News Distribution: Big Data Analysis of Naver News in 2000-2017. Korean J. J. Commun. Stud. 2017, 61, 74-109. (Written in Korean)

8. Kwak, K.T.; Hong, S.C.; Lee, S.W. A study of repetitive news display and news consumption in Korea. Telemat. Inform. 2020, 46, 101313. [CrossRef]

9. Kim, S.; Kim, W.; Park, A.; Yang, J. Digital News Report 2018; Korea Press Foundation: Seoul, Korea, 2018; pp. 9-50. ISBN 978-89-5711-530-5. (Written in Korean)

10. Ji, S.W.; Choi, Y.; Ryu, M.H. The economic effects of domestic search engines on the development of the online advertising market. Telecommun. Policy 2016, 40, 982-995. [CrossRef]

11. Kim, D.; Kim, S.W.; Kim, S. The Analysis of News Website Structure after the Introduction of Naver News-stand. J. Cybercommun. Acad. Soc. 2014, 31, 57-96, (Written in Korean).

12. Ahn, J.M. A Study on the Characteristics of the Portal News Service: Comparison between NHN's Newscast and Media Dotcom. J. Soc. Sci. 2009, 20, 101-124. (Written in Korean)

13. Cho, Y.; Yoo, S.; Han, Y.J. An Exploratory Study on the Relation of the Abusing of News Articles and the Portal Site's Supply System and Supplier's Status: Focusing on 'Naver'. Korean J. J. Commun. Stud. 2015, 59, 314-338. (Written in Korean)

14. Kim, I.H. Changes in the news ecosystem and prospects between portals and media companies: Both are concerned about survival in the mobile era through coexistence-subsidiary relations. Newspapers and Broadcasting, 6-9 September 2015. (Written in Korean)

15. Antolin-Lopez, R.; Martinez-del-Rio, J.; Cespedes-Lorente, J.; Perez-Valls, M. The choice of suitable cooperation partners for product innovation: Differences between new ventures and established companies. Eur. Manag. J. 2015, 33, 472-484. [CrossRef]

16. Yu, B.; Xu, H.; Dong, F. Vertical vs. Horizontal: How Strategic Alliance Type Influence Firm Performance? Sustainability 2019, 11, 6594. [CrossRef]

17. Inkpen, A.C.; Beamish, P.W. Knowledge, Bargaining Power, and the Instability of International Joint Ventures. Acad. Manag. Rev. 1997, 22, 177-202. [CrossRef]

18. Harrigan, K.R. Joint ventures and competitive strategy. Strateg. Manag. J. 1988, 9, 141-158. [CrossRef]

19. Kogut, B. Joint ventures: Theoretical and empirical perspectives. Strateg. Manag. J. 1988, 9, 319-332. [CrossRef]

20. Lopez-Navarro, M.A.; Molina-Morales, F.X. On measurement of joint ventures performance: A comparative approach. Int. J. Bus. Perform. Manag. 2002, 4, 115-127. [CrossRef]

21. Zhang, G.; Tang, C.; Qi, Y. Alliance Network Diversity and Innovation Ambidexterity: The Differential Roles of Industrial Diversity, Geographical Diversity, and Functional Diversity. Sustainability 2020, $12,1041$. [CrossRef]

22. Park, S.H.; Kim, D. Market valuation of joint ventures: Joint venture characteristics and wealth gains. J. Bus. Ventur. 1997, 12, 83-108. [CrossRef]

23. Russo, M.; Cesarani, M. Strategic Alliance Success Factors: A Literature Review on Alliance Lifecycle. Int. J. Bus. Adm. 2017, 8, 1-9. [CrossRef] 
24. Artz, K.W.; Brush, T.H. Asset specificity, uncertainty and relational norms: An examination of coordination costs in collaborative strategic alliances. J. Econ. Behav. Organ. 2000, 41, 337-362. [CrossRef]

25. Gulati, R. Social Structure and Alliance Formation Patterns: A Longitudinal Analysis. Adm. Sci. Q. 1995, 40, 619-652. [CrossRef]

26. Reuer, J.J.; Ariño, A. Strategic alliance contracts: Dimensions and determinants of contractual complexity. Strateg. Manag. J. 2007, 28, 313-330. [CrossRef]

27. Pak, Y.S.; Ra, W.; Park, Y.R. Understanding IJV performance in a learning and conflict mediated context. Int. Bus. Rev. 2009, 18, 470-480. [CrossRef]

28. Vickers, J. Delegation and the Theory of the Firm. Econ. J. 1985, 95, 138-147. [CrossRef]

29. Barajas, A.; Huergo, E.; Moreno, L. Measuring the economic impact of research joint ventures supported by the EU Framework Programme. J. Technol. Transf. 2011, 37, 917-942. [CrossRef]

30. Nielsen, B.B. Determining international strategic alliance performance: A multidimensional approach. Int. Bus. Rev. 2007, 16, 337-361. [CrossRef]

31. Wang, C.-N.; Nguyen, X.-T.; Wang, Y.-H. Automobile Industry Strategic Alliance Partner Selection: The Application of a Hybrid DEA and Grey Theory Model. Sustainability 2016, 8, 173. [CrossRef]

32. Yiu, D.; Makino, S. The Choice between Joint Venture and Wholly Owned Subsidiary: An Institutional Perspective. Organ. Sci. 2002, 13, 667-683. [CrossRef]

33. Lévesque, C.; Murray, G. Trade union cross-border alliances within MNCs: Disentangling union dynamics at the local, national and international levels. Ind. Relat. J. 2010, 41, 312-332. [CrossRef]

34. Das, T.K.; Teng, B.-S. Managing risks in strategic alliances. Acad. Manag. Perspect. 1999, 13, 50-62. [CrossRef]

35. Chang, M.H.; Liou, J.J.; Lo, H.W. A Hybrid MCDM Model for Evaluating Strategic Alliance Partners in the Green Biopharmaceutical Industry. Sustainability 2019, 11, 4065. [CrossRef]

36. Barney, J.B.; Hesterly, W.S. Strategic Management and Competitive Advantage: Concepts and Cases, 6th ed.; Pearson Education: London, UK, 2018; ISBN 978-0134741147.

37. Nakamura, M. Joint venture instability, learning and the relative bargaining power of the parent firms. Int. Bus. Rev. 2005, 14, 465-493. [CrossRef]

38. Delios, A.; Beamish, P.W. Joint venture performance revisited: Japanese foreign subsidiaries worldwide. Manag. Int. Rev. 2004, 44, 69-92. Available online: https://www.jstor.org/stable/40835978 (accessed on 10 March 2020).

39. Yang, J.; Lee, H. Identifying key factors for successful joint venture in China. Ind. Manag. Data Syst. 2002, 102, 98-109. [CrossRef]

40. Beamish, P.W.; Lupton, N.C. Managing joint ventures. Acad. Manag. Perspect. 2009, 23, 75-94. [CrossRef]

41. Reus, T.H.; Rottig, D. Meta-analyses of International Joint Venture Performance Determinants. Manag. Int. Rev. 2009, 49, 607-640. [CrossRef]

42. Venkatraman, N.; Ramanujam, V. Measurement of Business Performance in Strategy Research: A Comparison of Approaches. Acad. Manag. Rev. 1986, 11, 801-814. [CrossRef]

43. Bamford, J.; Ernst, D.; Fubini, D.G. Launching a world-class joint venture. Harv. Bus. Rev. 2004, 82, 90-100. Available online: https://hbr.org/magazine (accessed on 10 March 2020).

44. Büchel, B.; Thuy, L.X. Measures of joint venture performance from multiple perspectives: An evaluation by local and foreign managers in Vietnam. Asia Pac. J. Manag. 2001, 18, 101-111. [CrossRef]

45. Chong, H.G. Measuring performance of Chinese joint ventures. Adv. Account. 2009, 25, 81-88. [CrossRef]

46. Inkpen, A.C.; Currall, S.C. The Coevolution of Trust, Control, and Learning in Joint Ventures. Organ. Sci. 2004, 15, 586-599. [CrossRef]

47. Pothukuchi, V.; Damanpour, F.; Choi, J.; Chen, C.C.; Park, S.H. National and Organizational Culture Differences and International Joint Venture Performance. J. Int. Bus. Stud. 2002, 33, 243-265. [CrossRef]

48. Wang, Y.; Rajagopalan, N. Alliance Capabilities. J. Manag. 2014, 41, 236-260. [CrossRef]

49. Yan, A.; Gray, B. Bargaining Power, Management Control, and Performance in United States-China Joint Ventures: A Comparative Case Study. Acad. Manag. J. 1994, 37, 1478-1517. [CrossRef]

50. Kaplan, R.S.; Norton, D.P. The Balanced Scorecard: Measures that Drive Performance. Harvard Business Review 1992. January-February, pp. 71-79. Available online: https://hbr.org/magazine (accessed on 10 March 2020).

51. Massaro, M. Is business lobbying in the European Union context-dependent? Evidence from the policy field of radio spectrum. Telecommun. Policy 2019, 43, 101827. [CrossRef] 
52. Nanda, A.; Williamson, P. Unlocking your imprisoned assets: The joint venture solution. Eur. Manag. J. 1996, 14, 229-242. [CrossRef]

53. Kamminga, P.; van der Meer-Kooistra, J. Parents' Contribution and Management Control of Joint Ventures. Eur. Manag. J. 2006, 24, 226-235. [CrossRef]

54. Gill, J.; Butler, R. Cycles of trust and distrust in joint-ventures. Eur. Manag. J. 1996, 14, 81-89. [CrossRef]

(C) 2020 by the authors. Licensee MDPI, Basel, Switzerland. This article is an open access article distributed under the terms and conditions of the Creative Commons Attribution (CC BY) license (http://creativecommons.org/licenses/by/4.0/). 